\title{
DISCOORDINATED LABOR ACTIVITY AND MODERN APPROACHES TO ITS CORRECTION
}

The aim of the study - to evaluate the course and outcome of childbirth for the mother and the fetus by comparing various methods of correction of discoordinated labor activity (DLA).

Materials and Methods. 120 women in childbirth were examined, of whom 90 women had DLA. Group 1 (control) consisted of 30 women with a physiological course of childbirth, group 2-30 women in labor, who underwent correction of the DLA according to the order of the Ministry of Health of Ukraine No. 676, dated 12/31/2004, group 3-30 women who underwent epidural anesthesia, group 4 - 30 women who underwent complex treatment using phosphatidylcholine.

The subject of the study was indicators of partograms of women in labor, fetal CTG, levels of adrenaline, norepinephrine, prostaglandin F2 $\alpha$, oxytocin, dopplerometry, and assessment of the condition of newborns.

Results and Discussion. In women with DLA, a premature rupture of the membranes was determined in 67 (74.5\%); indicators of adrenaline were increased $(7.2 \pm 0.8) \mathrm{nmol} / \mathrm{l}$. Under the influence of treatment, the adrenaline level decreased in group 4 to $(3.5 \pm 0.5) \mathrm{nmol} / \mathrm{l}$. There was an increase in the concentration of PGF2a during DLA to $(177.2 \pm 6.9) \mathrm{ng} / \mathrm{ml}$. The use of traditional therapy reduced the content of PGF2a to $(134.1 \pm 5.1) \mathrm{ng} / \mathrm{ml}$, the use of phosphatidylcholine to $(111.7 \pm 4.8) \mathrm{ng} / \mathrm{ml}$. Similar changes were observed in oxytocin parameters: an increase in the content during DLA $(173.4 \pm 10.2) \mathrm{pg} / \mathrm{ml}$, a decrease under the influence of traditional treatment $(105.7 \pm 6.9) \mathrm{pg} / \mathrm{ml}$ and our proposed method of therapy $(91.3 \pm 5.6) \mathrm{pg} / \mathrm{ml}$.

The results of a Dopplerometric examination of women in labor with DLA indicated an increase in resistance in the uterine arteries and in the umbilical arteries. Studies have shown that in group 2, the Caesarean section was the lowest $-33.3 \%$, group 3 $-66.7 \%$, in group $4-40 \%$. Condition of the newborn: in group 2 of pregnant women in satisfactory condition $76.7 \%$ of newborns were born, in the group $3-66.7 \%$, in group $4-73.3 \%$.

Conclusions. Based on the results of the evaluation of the outcome of labor, the use of phosphothydiolcholine in the complex treatment of discordination of labor can significantly reduce the frequency of operative half-divergence and improve the condition of the fetus and the newborn due to the normalization of biologically active substances in the blood of the mother and fetus, improvement of blood flow in the utero-placental complex and, as a result of normalization of maternity activities.

Key words: discoordination of patrimonial activity; phosototidylcholine.

\section{ДИСКООРДИНОВАНА ПОЛОГОВА ДІЯЛЬНІСТЬ ТА СУЧАСНІ ПІДХОДИ ДО ЇЇ КОРЕКЦІї}

Мета дослідження - оцінювання перебігу і результату пологів для матері та плода шляхом порівняння різних методів корекції дискоординованої пологової діяльності.

Матеріали та методи. Було обстежено 120 роділей, з них 90 жінок мали в пологах дискоординовану пологову діяльність (ДПД). Першу групу (контрольну) склали 30 жінок із фрізіологічним перебігом пологів, другу - 30 роділей, яким проводили корекцію ДПД згідно з наказом МОЗ України № 676 від 31.12.2004, третю - 30 роділей із ДПД, яким проведено епідуральну анестезію, четверту - 30 жінок, яким проводили комплексне лікування з використанням сросфатидилхоліну.

Предметом дослідження були показники партограм роділей, КТГ плода, рівні адреналіну, норадреналіну, простагландину F2a, окситоцину, доплерометрії, оцінка стану новонароджених.

Результати дослідження та їх обговорення. У жінок із ДПД визначено передчасний розрив плодових оболонок у 67 (74,5 \%); показники адреналіну були підвищені - $(7,2 \pm 0,8)$ нмоль/л. Під впливом лікування рівень адреналіну зменшувався в четвертій групі до $(3,5 \pm 0,5)$ нмоль/л. Відмічали збільшення концентрації ПГन2а при ДПД до $(177,2 \pm 6,9)$ нг/мл. Використання традиційної терапії знижувало вміст ПГF2а до $(134,1 \pm 5,1)$ нг/мл, використання фоссратидилхоліну до $(111,7 \pm 4,8)$ нг/мл. Аналогічні зміни спостерігалися і в показниках окситоцину: підвищення вмісту при ДПД - $(173,4 \pm 10,2)$ пг/мл, зниження під

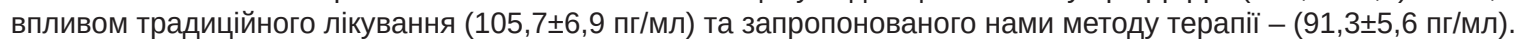

Отримані результати доплерометричного обстеження роділей із ДПД вказували на підвищення резистентності в маткових артеріях та в артеріях пуповини.

Дослідження показали, що в другій групі був найнижчий рівень кесаревого розтину - 33,3 \%, у третій - 66,7 \%, у четвертій - 40 \%. Стан новонародженого: у другій групі вагітних у задовільному стані народилося 76,7 \% новонароджених, у третій групі - 66,7 \%, у четвертій групі - 73,3\%.

Висновки. За результатами оцінювання результату пологів, використання фоосфатидилхоліну в комплексному лікуванні дискоординації пологової діяльності дозволяє значно знизити частоту оперативного розродження та покращити стан плода й новонародженого за рахунок нормалізації біологічно активних речовин у крові матері та плода, покращення кровотоку в матково-плацентарному комплексі і, як результат, - нормалізувати пологову діяльність.

Ключові слова: дискоординація пологової діяльності; фоосратидилхолін.

ДИСКООРДИНИРОВАННАЯ РОДОВАЯ ДЕЯТЕЛЬНОСТЬ И СОВРЕМЕННЫЕ ПОДХОДЫ К ЕЕ КОРРЕКЦИИ

Цель исследования - оценивание течения и исхода родов для матери и плода путем сравнения различных методов коррекции дискоординированной родовой деятельности.

Материалы и методы. Было обследовано 120 рожениц, из них 90 женщин имели в родах дискоординированную родовую деятельность (ДРД). Первую группу (контрольную) составили 30 женщин с фризиологическим течением родов, вторую - 30 
рожениц, которым проводилась коррекция ДРД согласно приказу МОЗ Украины № 676 от 31.12.2004, третью - 30 рожениц с ДРД, которым проведена эпидуральная анестезия, четвертую - 30 женщин, которым проводилось комплексное лечение с использованием фросфатидилхолина.

Предметом исследования были показатели партограмм рожениц, КТГ плода, уровни адреналина, норадреналина, простагландина F2a, окситоцина, допплерометрия, оценка состояния новорожденных.

Результаты исследования и их обсуждение. У женщин с ДРД определялся преждевременный разрыв плодных оболочек у 67 (74,5 \%); показатели адреналина были повышены - (7,2士0,8) нмоль/л. Под влиянием лечения уровень адреналина уменьшался в четвертой группе до $(3,5 \pm 0,5)$ нмоль/л. Отмечалось увеличение концентрации ПГF2a при ДРД до $(177,2 \pm 6,9)$ нг/мл. Использование традиционной терапии снижало содержание ПГF2а до $(134,1 \pm 5,1)$ нг/мл, использование фоссратидилхолина до 111,7+4,8нг/мл. Аналогичные изменения наблюдались и в показателях окситоцина: повышение

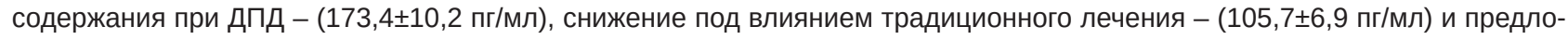

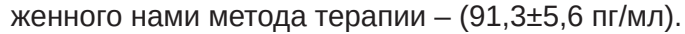

Полученные результаты допплерометрического обследования рожениц с ДРД указывали на повышение резистентности в маточных артериях и в артериях пуповины.

Исследования показали, что во второй группе был самый низкий уровень кесарева сечения - 33,3 \%, в третьей - 66,7 \%, в четвертой - 40 \%. Состояние новорожденного: во второй группе беременных в удовлетворительном состоянии родилось $76,7 \%$ новорожденных, в третьей группе $-66,7 \%$, в четвертой группе $-73,3 \%$.

Выводы. По результатам оценивания исхода родов, использование фоссратидилхолина в комплексном лечении дискоординации родовой деятельности позволяет значительно снизить частоту оперативного родоразрешения и улучшить состояние плода и новорожденного за счет нормализации биологически активных веществ в крови матери и плода, улучшения кровотока в маточно-плацентарном комплексе и, как результат, - нормализировать родовую деятельность.

Ключевые слова: дискоординация родовой деятельности; фроссратидилхолин.

INTRODUCTION. Among the abnormalities of labor activity, the frequency of which reaches 18-20\%, the important place is the discoordination of labor activity (DLA) - the violation of the coordination of contractions of different units of the uterus (right and left, upper and lower). It is known that DLA leads to a high frequency of operative delivery, maternal injury, pathological blood loss, postpartum septic complications, maternal and perinatal morbidity $(107,152)$. Among the causes of DLA are anomalies of the development of the uterus, violation of its innervation as a result of abortion, inflammatory processes, tumor formations. An unfavorable background of the DLA is the lack of training for all structures involved in the maternity ward (absence of birth defects, neurohormonal disorders, immature cervix, rhythm driver migration, etc.) [45].

According to the analysis of the literature on the location of the DLA in the classification of abnormalities in labor activity (ALA), isolated results were obtained that are characterized by a lack of a single point of view. The most common classification of anomalies of contractile activity of the uterus is the classification of $\mathrm{H}$. Alvarez and R. Cardeyro-Barcia (1954), which was based on the theory of "triple descending gradient", according to which all ALAs are divided into 3 groups: quantitative anomalies, qualitative anomalies and cervical dystonia.

The basis of modern western classifications is the classification of $\mathrm{H}$. Yung (1974), which combines all forms of anomalies of labor with one concept - dystocia. For clinical purposes, the following division of pathological forms of contractile activity of the uterus is proposed: 1) weakness of abbreviations; 2) hyperactive generic activities; 3) hypertonic labor, arising from the passive stretching of the uterus, essential hypertension, tachysystoles.

In foreign literature, there are other categories of contractions of the uterus. Thus, according to E.A. Fridman (1983), the following types of anomalies of contractile activity are distinguished: 1) a prolonged latent phase of disclosure; 2) prolonged active phase of disclosure; 3 ) secondary stop of the opening of the cervix; 4) prolonged phase of deceleration.
N.Beicher (1986) highlights: 1) primary and secondary hypoactivity or inactivity of the uterus; 2) coordinated hyperactivity of the uterus (rapid births, retraction ring); 3 ) discorporated labor (hypertonic lower segment, contraction ring, uterine tetany, cervical dystocia, false childbirth).

According to the International Statistical Classification of Diseases and Health-Related Issues, the WHO Review (Geneva, 1995), the clinical classification of the ALA has the following form: primary malnutrition; secondary weakness of labor activity; other types of maternal weaknesses (uterine atony, disordered contractions, hypotonic dysfunction of the uterus); rapid childbirth; hypertonic, uncoordinated and prolonged contractions of the uterus (a contraction ring, dystocia, dyadicated labor, uterine contraction in the form of a sand hour, hypertonic dysfunction of the uterus, tetanus disturbances, uterine dystocia).

After analyzing the available literature, we came to the conclusion that the concept of "discorporated labor" is a rather complex and controversial situation. On the one hand, the International Classification (Geneva, 1995), which is used in our country in accordance with the Ministry of Health orders and clinical protocols, provides for the possibility and necessity of separating from a large number of abnormalities of labor activity not only DLA but also its specific variants. On the other hand, in English-language scientific literature, the terminological notion of DLA is practically not used in recent years, and if used, then out of context with the real problems of practical obstetrics.

Despite the obvious progress in the study of mechanisms of regulation of uterine activity, the nature of the anomalies of labor and their pathogenesis remain far from complete comprehension. It is established that the main linkages of the pathogenesis of DLA development are violation of vegetative equilibrium due to the imbalance of parasympathetic and sympathetic systems, the issue of receptor, biochemical and molecular mechanisms of regulation of contractile function of the uterus $(94,107)$. In the scientific literature of recent years, there is an increasing number of works of domestic and foreign authors, which note the significant role of the 
adrenergic nervous system in the regulation of contractile activity of the uterus. Interest in this problem is due to the fact that researchers managed to decipher the mechanisms of synthesis, accumulation and inactivation of the mediator adrenergic nervous system norepinephrine with the participation of presynaptic adrenergic receptors. As you know, the main adrenergic mediators of catecholamines are adrenaline and norepinephrine, which can stimulate an increase in uterine contractions, or, conversely, cause depression of labor. The physiological response of catecholamines is carried out by their action on adrenergic receptors. Having studied the contractile activity of myometrium and blood catecholamines during physiological and pathological births, the researchers came to the conclusion that adrenaline excites the contractile labor of the non-pregnant uterus and inhibits spontaneous oral activity, while norepinephrine causes contraction of the pregnant uterus. Consequently, it was concluded that reducing the amount of adrenaline and increasing the content of norepinephrine in the uterus is one of the mechanisms that induce the onset of labor [29].

The question of regulation of $\beta$-adrenoreactivity myometry in pregnant women and its role in the occurrence of DLA remains open. It is through this process that the suppression of spontaneous and caused contractile activity of myocytes during pregnancy is suppressed, and prenatal reduction of the degree of this effect is a necessary step in the development of labor activity [2].

Circulatory disturbances in the uteroplacental pool can lead to an inadequate increase in tone, changes in rhythm and frequency of prime, shortening of diastole, increased pain due to residual blood accumulation in the intervertebral space [107].

Despite the obvious progress in the study of mechanisms of regulation of uterine activity, the nature of DLA and its pathogenesis remain far from complete comprehension.

Among the DLA treatment options, known uses of medication sleep, anesthetics, analgesics, granaxin, $\beta$-adrenergic agents (ginapril) and others $(2,63,183)$. In addition to drug correction, DLA is aware of the positive effects of regional anesthesia, which provides sufficient miorelaxation, adequately relieves contractions, acts spasmolitine on the cervix, coordinates labor activities [53]. There are a number of non-medicated methods for treating DLA-acupuncture acupressure, aromatherapy, hypothermia, and others, but there is still no single effective algorithm for correction of this pathology [45]. Since the frequency of operational degeneration and adverse perinatal effects in women with DLA remains high, the development of the principles of correction of this abnormality of contractile function of the uterus is an urgent task of modern obstetrics.

Recently, attention has been paid to the use of phospholipids in medical practice and, in particular, phosphotyldilcholine (PC) [50]. The metabolic peculiarity of PC is the high rate of biotransformation, the half-life of which in blood plasma reaches 24 hours, and in cytoplasmic membranes ranges from several hours to 2-3 days. It is believed that the main biochemical function of PC is to participate in the formation and function of cell membranes, which consist mainly of proteins and lipids. Membrane phospholipids are mainly PC and sphingomyelin, PC is considered to be the main component of the cell membrane and is located on its outer surface, ensuring the transfer through it of substances with different chemical structure and physical and chemical properties. An important function of PC is its participation in the synthesis of prostaglandins, which is very important in the regulation of contractile function of the uterus. To the biological properties of PC include its neurotropic effect, which contributes to a decrease in fatigue, improvement of attention, memory, with which PC is used in therapeutic, neurological and pediatric practice [50].

THE AIM OF THE STUDY - to evaluate the course and outcome of childbirth for the mother and the fetus by comparing various methods of correction of discordial labor; the parameters of partogramming, the changes occurring in the delivery pathways and the rate of opening of the uterine eye, the results of the hysterography and CTG of the fetus (AvalonFM 30, the Netherlands), analysis of the dynamics of the levels of biologically active substances (adrenaline and norepinephrine), prostaglandin $\mathrm{F} 2 \alpha$, endogenous oxytocin, identified by immunoassay analysis using the commercial sets "Sunrise, Tecan" (Austria), hemodynamics in the uterine vessels and vessels of the phytoplankter complex was determined by doplerometric flow Outcome using the ultrasound apparatus "Phillips HD 11 XE" (Germany), assessment of the state of newborns was carried out on the Apgar scale in conjunction with a neonatologist. Statistical processing of the results was carried out using the "Statistica 6.0" computer program.

MATERIALS AND METHODS. To achieve the goal, 120 families were surveyed, of whom 90 women had DLAs (the main group). Group 1 (control) consisted of 30 women with a physiological course of labor. Group 2 included 30 breeding grounds, which was corrected by the DLA in accordance with the order of the Ministry of Health of Ukraine No. 676, dated December 31, 2004. Clinical group 3 consisted of women with DLA, which was used for the correction of labor activity by regional (epidural) anesthesia (30 women) with the introduction of anesthetics in the subarachnoidal space. Clinical group 4 - women, who underwent a drug correction of the DLA with a medicinal product, the active base of which is phosphatidylcholine (30 women), the manufacturer of Biolek (Ukraine). Phosphatidylcholine has antihypoxic action, promotes an increase in the rate of diffusion of oxygen from the lungs in blood and blood in tissue, normalizes processes of tissue respiration, restores functional activity of endothelial cells, synthesis and allocation of endothelial factor of relaxation, improves microcirculation and rheological properties of blood. Phosphatidylcholine inhibits the processes of peroxidation of lipids in blood and tissues, supports the activity of antioxidant systems of the body, makes the membrane-protective effect, performs the function of a non-specific detoxifier, improves nonspecific immunity. The drug was administered at a dose of $5-10 \mathrm{mg} / \mathrm{kg}$ massothelium. Drip was administered intravenously, slowly.

RESULTS AND DISCUSSION. The average age of pregnant women with discoordination of labor activity was $(25.8 \pm 3.6)$ years, in the control group - $(23.9 \pm 2.5)$ years. Primiparous in the main group were 72 women (80\%), in control - 25 women (83.3 \%). In all women, pregnancy was desirable, single-sided, the position of the fetus - longitudinal, fetal presentation - occipital. Premature rupture of the mucous membranes was determined in 67 (74.5\%) women with DLA and in 21 women (70 \%) in the control group. The mature state of the cervix on the Bishop scale in the preg- 
nancy of the main group was $13.3 \%$. Women in the main group complained of painful contractions, according to CTG data and data of vaginal examination, a diagnosis of DLA was established, in connection with which the DLA therapy was prescribed in line with the clinical groups.

Indicators of adrenalin with DLA were elevated (7.2 \pm $0.8) \mathrm{nmol} / \mathrm{L}$, while the level of norepinephrine (38.4 \pm 2.9) $\mathrm{nmol} / \mathrm{L}$ did not exceed the physiological limit. Under the influence of treatment, the level of adrenalin decreased to $(4.2 \pm 0.6) \mathrm{nmol} / \mathrm{L}$, to a greater extent in the fourth group under the influence of phosphatidylcholine $(3.5 \pm 0.5) \mathrm{nmol} / \mathrm{L}$. The level of norepinephrine practically did not change. Attention was drawn to the probable increase in the concentration of PGF2 $\alpha$ in DLA compared with normal values (177.2 \pm 6.9) $\mathrm{ng} / \mathrm{ml}$, which may indicate its pathogenetic role in the development of DLA. The use of traditional therapy reduced the content of PGF2 $\alpha$ to $(134.1 \pm 5.1) \mathrm{ng} / \mathrm{ml}$, since it is not as effective as the use of phosphatidylcholine (111.7 \pm 4.8) $\mathrm{ng} / \mathrm{ml}$. Similar changes were observed in the indicators of endogenous oxytocin: the increase in content in the DLA - (173.4 \pm 10.2$) \mathrm{pg} / \mathrm{ml}$, decrease under the influence of traditional treatment $(105.7 \pm 6.9) \mathrm{pg} / \mathrm{ml}$ and the proposed treatment method $(91.3 \pm 5.6) \mathrm{pg} / \mathrm{ml}$.

The results of the dopplerometric examination of the rodel with DLA indicated an increase in resistance in the uterine arteries and umbilical arteries, which negatively affects the contractile function of the uterus and the condition of the fetus, causing pathological changes, as determined by CTG data.

Studies have shown that in group 2, where the correction of labor activity was conducted in accordance with the order of the Ministry of Health of Ukraine No. 676, from December 31, 2004, the lowest level of caesarean was $33.3 \%$. In group 3, where the correction of DLA was performed using regional anesthesia, the percentage of the frequency of cesarean fraction reached $66.7 \%$. In group 4 , where the correction of DLA was carried out with the drug, the active substance of which is phosphatidylcholine, the number of genera that resulted in surgical intervention was $40 \%$. Taking into account the data of the partograms of the main group, in which the delivery was over physiologically, we can say that in 2 and 4 groups the number of births decreased, the frequency of occurrence of early and late deceleration. The condition of the newborn in different clinical groups demonstrated the following results: $100 \%$ of the control pregnant women were born to live births of babies with an Apgar score of 9-10 points. In group 2 of pregnant women in satisfactory condition (8-9 points on the Apgar scale) $76.7 \%$ of newborns were born, in group $3-66.7 \%$, in group $4-73.3 \%$.

Thus, an effective method of complex DLA correction is the use of a drug whose active substance is phosphatidylcholine in addition to the recommendation of the Ministry of Health of Ukraine, which is confirmed by the clinical, instrumental and biochemical parameters determined during the study. Based on the data obtained, it is possible to optimize the process of correction of DLA taking into account the condition of the women and the condition of the fetus, to minimize the cost of treatment of the women with DLA in childbirth, to reduce the percentage of surgical interventions, to reduce the number of obstetric and perinatal complications.

CONCLUSIONS. Based on the results of the evaluation of the outcome of labor, the use of phosphothydiolcholine in the complex treatment of discordination of labor can significantly reduce the frequency of operative half-divergence and improve the condition of the fetus and the newborn due to the normalization of biologically active substances in the blood of the mother and fetus, improvement of blood flow in the utero-placental complex and, as a result of normalization of maternity activities.

FURTHER RESEARCH PERSPECTIVES. Determination of the pathogenetic effect of phosphatidylcholine in the treatment of DLA according to morphological and immunohistochemical examination of myometrium and placenta.

\section{LITERATURE}

1. Щедров А. А. Значение повреждения эндотелия и его вазорегулирующей способности в развитии аномалий родовой деятельности / А. А. Щедров // Актуальні проблеми сучасної медицини. - 2012. - № 3. - С. 166-169.

2. Karaçam Z. D. Evolving understanding and treatment of labour dystocia / Z. Karaçam, D. Walsh, G. J. Bugg // Eur. J. Obstet. Gynecol. Reprod. Bio. - 2014. - Vol. 182. - P. 123-127.

3. Козонов Г. Р. Дискоординации родовой деятельности: теория и практика / Г. Р. Козонов // Ученые записки СПбГМУ им. акад. И. П. Павлова. - 2014. - №1. - С. 79-81.

4. Ткачик С. Я. Особенности концентрации метаболитов стероидных гормонов при дискоординированной родовой деятельности / С. Я. Ткачик // Здоровье женщины. - 2013. - № 5. - С. 94-96.

5. Дмитриева С. Л. Роль адренергического механизма в регуляции сократительной деятельности матки при беременности и в родах : обзор литературы / С. Л. Дмитриева С. В. Хлыбова, В. И. Циркин // Вятский медицинский журнал. - 2012. - № 1. - С. 50-53.
6. Абрамченко В. В. Пролонгирование эффректа бетаадреномиметиков (гинипрала) в сочетании с комплексом унитиол-аскорбиновая кислота / В. В. Абрамченко, Е. В. Костюшов, Н. Р. Данилова // Проблемы репродукции. - 2001. - № 4. - С. 51-52.

7. Паращук Ю. С. Диагностика и фрармакологическая коррекция дискоординации родовой деятельности / Ю. С. Паращук, 3. А. Горшкова // Врачебная практика. - 2003. - № 5. - C. 61-64.

8. Schrock S. D. Labor analgesia / S. D. Schrock, C. Harraway-Smith // Am. Fam. Physician. - 2012. - Vol. 85 (5). P. 447-454.

9. Методи регіонарної аналгезії в пологах / О. В. Голяновський, В. В. Мехедко, А. А. Жежер [та ін.] // Здоровье женщины. - 2012. - № 6. - С. 71-75.

10. Новые аспекты клинического применения в акушерстве : метод. рек. / В. В. Симрок, О. В. Грищенко, А. В. Сторчак, Б. М. Липин. - 2007. - 40 с. 


\section{REFERENCES}

1. Shchedrov, A.A. (2012). Znacheniye povrezhdeniya endoteliya i yego vazoreguliruyushchey sposobnosti v razviti anomaliy rodovoy deyatelnosti [The value of endothelial damage and its vasoregulatory ability in the development of anomalies of labor]. Aktualni problemy suchasnoi medytsyny - Actual Problems of Modern Medicine, 3, 166-169 [in Russian].

2. Karaçam, Z.D., Walsh, D., \& Bugg, G.J. (2014). Evolving understanding and treatment of labour dystocia. Eur. J. Obstet. Gynecol. Reprod. Bio., 182, 123-127.

3. Kozonov, G.R. (2014). Diskoordinatsii rodovoy deyatelnosti: teoriya i praktika [Discoordination of patrimonial activity: theory and practice]. Uchenyye zapiski SPbGMU im. akad. I. P. Pavlova - Scientific notes of St. Petersburg SMU Acad. I. P. Pavlova, 1, 79-81 [in Russian].

4. Tkachik, S.Ya. (2013). Osobennosti kontsentratsii metabolitov steroidnykh gormonov pri diskoordinirovannoy rodovoy deyatelnosti [Features of the concentration of metabolites of steroid hormones during discoordinated labor]. Zdorovye zhenshchiny - Women's Health, 5, 94-96 [in Russian].

5. Dmitriyeva, S.L., Khlybova, S.V., \& Tsirkin, V.I. (2012). Rol adrenergicheskogo mekhanizma $v$ regulyatsii sokratitelnoy deyatelnosti matki pri beremennosti i v rodakh: (obzor literatury) [The role of the adrenergic mechanism in the regulation of contractile activity of the uterus during pregnancy and childbirth: (literature review)]. Vyatskiy meditsinskiy zhurnal - Vyatka Medical Journal, 1, 50-53 [in Russian].

6. Abramchenko, V.V., Kostyushov, Ye.V., \& Danilova, N.R. (2001). Prolongirovaniye effekta beta-adrenomimetikov (giniprala) v sochetanii s kompleksom unitiol-askorbinovaya kislota [Prolongation of the effect of beta-adrenergic agonists (ginipral) in combination with the unitiol-ascorbic acid complex]. Problemy reproduktsii - Problems of Reproduction, 4, 51-52 [in Russian].

7. Parashchuk, Yu.S., \& Gorshkova, Z.A. (2003). Diagnostika i farmakologicheskaya korrektsiya diskoordinatsii rodovoy deyatelnosti [Diagnostics and pharmacological correction of discoordination of labor]. Vrachebnaya praktika-Medical Practice, 5, 61-64 [in Russian].

8. Schrock, S.D., \& Harraway-Smith, C. (2012). Labor analgesia. Am. Fam. Physician, 85 (5), 447-454.

9. Holianovskyi, O.V., Mekhedko, V.V., Zhezher, A.A., Kulakovskyi, M.M., \& Bachynska, M.A. (2012). Metody rehionarnoi analhezii v polohakh [Methods of regional analgesia in childbirth]. Zdorove zhenshchiny - Womens Health, 6, 71-75 [in Ukrainian].

10. Simrok, V.V., Grishchenko, O.V., Storchak, A.V., \& Lipin, B.M. (2007). Novyye aspekty klinicheskogo primeneniya $\checkmark$ akusherstve: metodicheskiye rekomendatsii [New aspects of clinical use in obstetrics: guidelines] [in Russian].

Received 20.11.19 